\title{
Social skills in crack users: differences between men and women
}

\author{
Ilana Andretta ${ }^{*} \mathbb{D}$, Jéssica Limberger and Jaluza Aimèe Schneider
}

\begin{abstract}
Low levels of social skills in drug users are reported in the literature. However, specific characteristics of these users need to be identified and comprehended. Thus, we aim to evaluate and compare the social skills of men and women crack users and to determine the existence or not of differences in these behaviors. A cross-sectional, quantitative, and comparative research was performed. A total of 127 (65 men and 62 women) crack users in treatment for drug use participated in the study. Results demonstrate significantly higher averages of social skills among women than among men in the total score $(t=2.020 ; p=0.046)$, self-assertion in the expression of positive affect $(t=2.755 ; p=0.007)$, and conversation and social confidence $(t=2.101 ; p=0.038)$. In conclusion, there is a unique repertoire of social skills in men and women in this study, showing that among men crack users, there were greater difficulties in the expression of positive feelings and social confidence, while there was more difficulty in expressing unpleasantness and dealing with negative feelings among women. Thus, this study emphasizes the importance of the development of interventions focused on learning and improving social skills for the crack user population, considering the differences between men and women.
\end{abstract}

Keywords: Crack cocaine, Men, Women, Disorder related to substance use, Social skills

\section{Background}

Social skills (SS) are a set of behaviors issued by a person in its social environment, where it will express its feelings, needs, and rights in an adaptive and assertive manner, decreasing the likelihood of the emergence of future problems arising from this interaction (Caballo, 2003). Therefore, social skills may be assessed not only in a general context but also on the existence of different classes of social behaviors, in order to deal with various demands of everyday interpersonal situations (Del Prette \& Del Prette, 2001).

Del Prette and Del Prette (2001) name five factors of social skills, understood as situational, from the Social Skills Inventory (SSI-Del Prette), which will be further described. Coping and self-assertion with risk indicates the ability to deal with interpersonal situations that require affirmation and defense of rights, entailing the risk of an undesirable reaction. Self-assertion in the expression of positive affect is composed of skills like praising and acknowledging compliments, defending another person in a group, and participating in trivial conversation.

\footnotetext{
* Correspondence: ilana.andretta@gmail.com

Universidade do Vale do Rio dos Sinos, São Leopoldo, Brazil
}

Conversation and social confidence portrays the skill to deal with situations with minimal risk of an unwanted reaction, from daily relationship standards. Self-exposure to unknown people and new situations includes the approach of unknown people at a greater risk of unwanted reactions from the other. Finally, self-control of aggressiveness in aversive situations indicates the expression of unpleasantness or anger in a socially competent manner (Del Prette \& Del Prette, 2001).

Different sociodemographic aspects influence the social skills. Among them, gender is emphasized, since learning social skills occurs differently for men and women (Bolsoni-Silva et al. 2011; Caballo, 2003). Since childhood, social behaviors are directly influenced by the roles of social genders, which are reinforced by caregivers, differentiating the learning mode of sociability between the genders (Papalia \& Feldman, 2013).

With regard to the adult population, the literature indicates differences in social skills between men and women in different contexts. A study performed with the population of 18 countries, including Latin America and also Portugal and Spain, identified that women had higher levels of anxiety or fear toward different social 
situations involving possible evaluation of another person, reflecting in more difficulties in interpersonal relationships with the female population (Caballo et al. 2014). A Brazilian study with 126 college students reported that women had higher expression of positive affects kills and self-exposure to unknown people and new situations when compared to men (Bartolomeu et al. 2008). Also in Brazil, a study with 80 participants found no differences in social skills of alcohol users compared to nonusers. However, when analyzing the gender of the participants, men had higher averages in self-control of aggressiveness, conversation, and social confidence (Aliane et al. 2006). Due to the presented evidence, the important role that gender has about social skills repertoire is emphasized (Caballo, 2003).

In the context of drug use, the literature evidences low SS in users of different licit and illicit drugs (Alexandre et al. 2004; Cunha et al. 2012; Cunha et al. 2007; Sá \& Del Prette, 2011; Sintra et al. 2011; Wagner \& Oliveira, 2015). However, there is a lack of studies regarding the differences in social skills between men and women users. According to a systematic review on the topic, of 13 articles analyzed, no study had mainly aimed to assess the differences in social skills between genders (Schneider et al. 2016). Nevertheless, there are some contributions, as a study performed in Germany, which highlight that there are higher rates of interpersonal problems among women alcohol users when compared with men also alcohol users (Muller et al. 2009). Another study, on the rehabilitation process after treatment for drug use, found that women had more pronounced difficulties with social interactions than men (Kuri et al. 2015).

Characteristics of consumption pattern and the type of drug used may also influence the social skills repertoire of individuals (Sá \& Del Prette, 2014). Crack is considered a substance with high rates of dependency and biopsychosocial losses. It is reported that its users tend to break affective and professional interpersonal relationships, resulting in poor social interaction (Limberger \& Andretta, 2017; Kessler et al., 2012; Ribeiro \& Laranjeira, 2012; Spronk et al. 2013).

Differences in crack consumption pattern are also identified between men and women, as the initial motivation to use it and symptoms of dependence (Muller et al., 2009; Pasa \& Almeida, 2010). Moreover, there are specific risk factors for the use of stimulants in women, for instance, the relationship with other drug users (APA, 2014). Thus, some women start to consume crack because of the companionship feeling and for fear of being criticized by those who offer them the drug, which is not a significant factor in the onset of crack use among men (Ribeiro \& Laranjeira, 2012). Given in the above, studies indicate the need for interventions that promote the learning and/or improvement of the social behavior repertoire of drug users, for instance, the social skills training (SST), contributing to the social reinsertion after the treatment (Caballo, 2003; Diehl et al. 2011; Fischer et al., 2015; Kuri et al. 2015).

It is hypothesized that there are also differences in social skills of men and women crack users, considering the differences between genders in learning social skills and in drug consumption. The identification of such differences is essential to support interventions, contributing to the treatment and social reinsertion. Thus, this study aims to assess and compare the social skills of men and women crack users to verify the existence or not of differences in such behaviors, indicating directions to the SST with this population.

\section{Methods}

Study design

This study is a cross-sectional quantitative comparative study (Sampieri et al. 2013).

\section{Participants}

A total of 127 individuals participated in the study, of which 65 men and 62 women, abstinent for at least 7 days. They were in closed hospital treatment for Substance Use Disorder, for crack use. The places of treatment were therapeutic communities and general hospitals. We excluded from the study individuals who had cognitive impairment and/or psychotic syndrome.

Mean age of men was 32.23 years ( $\mathrm{SD}=7.58$ years), and the majority was single $(n=26 ; 40.6 \%)$, with incomplete or complete elementary school $(n=38 ; 58.5 \%)$ and belonged to the lower class $(n=37,58.7 \%)$. They reported having worked before hospitalization $(n=52$, $80 \%$ ), having relatives who also had problems with substance use $(n=52,81.3 \%)$, and they were parents of at least one child ( $n=47,74.6 \%$ ).

Women who participated in this study were in the majority single $(n=39 ; 62.9 \%)$, with incomplete elementary school $(n=31 ; 50 \%)$, belonged to the lower class $(n=32$; $52.7 \%)$, and with a mean age of 33.45 years $(\mathrm{SD}=8.14)$. Before hospitalization, $51.6 \%(n=32)$ of women said they had worked, belonged to the lower class $(n=32 ; 51.7 \%)$, had at least one child $(n=58 ; 93.5 \%)$, and also had relatives with problems related to drug use $(90.3 \% ; n=56)$.

No statistically significant differences were found between men and women in relation to age $(t=-0.873$; $p=0.384)$ and schooling $\left(\chi^{2}=10.169 ; p=0.118\right)$. These variables were analyzed by the Student's $t$ test and chisquare test, respectively.

\section{Instruments}

Questionnaire of sociodemographic data and about drug use This questionnaire was developed by the research group "Intervenções Cognitivo-Comportamentais: Estudo e Pesquisa (ICCEP)," aiming to assess sociodemographic 
data, Criteria of Economic Classification Brazil, Brazilian Association of Research Companies (ABEP, 2015), family data, and standard use of drugs (types and time of use for each used drug), as well as data regarding the treatment and DSM-5 criteria (APA, 2014) for the diagnosis of substance use disorders.

\section{Mini International Neuropsychiatric Interview (MINI)}

This is a short structured clinical interview, of free access and compatible with the diagnosis criteria of DSMIV-TR (APA, 2002). It was developed by Sheehan et al. (1998) and validated for Brazil by Amorim (2000), with satisfactory Kappa indices, demonstrating reliability in diagnostic categories (from 0.86 to 1 ) and psychotic disorders (from 0.62 to 0.95 ) (Amorim, 2000). The interview was used to assess the exclusion criterion related to the presence of the psychotic syndrome.

\section{Cognitive screening protocol of WAIS-II}

This test is used exclusively by psychologists, and it was developed by Wechsler (1997), adapted and standardized for Brazil by Nascimento (2004). Cognitive impairment is indicated if, by subtracting the weighted scored of vocabulary from the weighted score of cubes, there is a difference of three points or more, as shown by Cunha (1993), Feldens et al. (2011). The protocol was used to assess the presence of the exclusion criterion regarding the existence of cognitive impairment.

\section{Social Skills Inventory (SSI)}

Developed by Del Prette and Del Prette (2001), this test is used exclusively by psychologists and aims to characterize the social skills in different situations: work, school, family, and everyday life. The inventory is a self-report, composed of 38 items, a five-point Likert scale, which ranges from never or rarely to always or almost always. It has Cronbach's Alfa coefficient of 0.75 and test-retest stability $(r=0.90 ; p=0.001)$. Factorial analysis of the instrument revealed a five-factor structure that gathers social skills of (1) coping and self-assertion with risk, (2) self-assertion in the expression of positive affect, (3) conversation and social confidence, (4) self-exposure to unknown people and new situations, (5) self-control of aggressiveness. The results were calculated based on the simple average of the values obtained, as shown by Del Prette \& Del Prette (2001). Values in the 50th percentile showed median position, values above $75 \%$ indicated high factors in social skills, and values below 25\% indicated deficits in social skills repertoire (Del Prette \& Del Prette, 2001).

\section{Procedures}

This study is part of a larger research project named "Assessment and social skills training of substance dependents in specialized drug treatment facilities," approved by the Ethics Committee under the report number 13.172 . The locations (therapeutic communities and general hospitals) were chosen for convenience and were located in the metropolitan and northwest region of the State of Rio Grande do Sul (Brazil).

After an individual explanation of the aims of the study, participants who agreed to participate signed the Free and Clarified Consent Term. Data were collected over a period of 6 months by members of the research group, constituted by psychologists and psychology students, all with proper training for the implementation of each instrument. The instruments were applied individually in rooms provided at the very place of treatment.

\section{Data analysis}

Data were analyzed through the Statistical Package for Social Sciences (SPSS), version 20.0. Descriptive analysis contemplated frequencies, percentages, average, median, and standard deviation of the sample, with a study of data distribution by the Kolmogorov-Smirnov test. The chi-square test was used to compare the categorical variable schooling and the Student's $t$ test to compare age. Student's $t$ test was used to compare means of social skills between men and women. A significance level of $5 \%(p \leq 0.05)$ was adopted for statistical decision criteria.

\section{Results}

Assessment of social skills from the Social Skills Inventory (Del Prette \& Del Prette, 2001) indicated that women had deficits in conversation and social confidence skills $(40.3 \% ; n=25)$, self-control of aggressiveness $(38.7 \% ; n=24)$, and self-exposure to unknown people and new situations $(35.5 \% ; n=22)$. In men, it was identified deficits in the overall score $(43.1 \% ; n=28)$, conversation and social confidence (47.7\%; $n=31$ ), and to self-control aggressiveness in aversive situations $(32.3 \% ; n=21)$.

In comparing the social skills of men and women crack users, women had significantly higher total scores $(t=2.020 ; p=0.046)$ in self-assertion in the expression of positive affect $(t=2.755 ; p=0.007)$ and in conversation and social confidence $(t=2.101 ; p=0.038)$, when the results of the Social Skills Inventory were compared between men and women. Further details can be observed in Table 1.

Significant statistical differences were found when social skills of men and women were compared to each item of the IHS-Del-Prette (Table 2). It was reported that men had higher social skills of public presentations or lectures to an unknown public, addressing a partner for sexual intercourse, dealing with unfair and fair criticism, returning defective product to the store, ending a telephone conversation, greeting strangers, dealing with parent's criticism and with offensive mockery or games, and asking a favor from colleagues. On the other hand, 
Table 1 Comparison of social skills of men and women crack users

\begin{tabular}{|c|c|c|c|c|c|c|}
\hline Social skills ${ }^{a}$ & Sex & $n$ & Mean & SD & $t$ & $p$ \\
\hline \multirow[t]{2}{*}{ Total score } & Women & 62 & 93.112 & 14.471 & 2.020 & $0.046^{*}$ \\
\hline & Men & 65 & 88.323 & 12.199 & & \\
\hline \multirow{2}{*}{$\begin{array}{l}\text { Coping and self-assertion } \\
\text { with risk }\end{array}$} & Women & 62 & 2.252 & 0.607 & -6.664 & 0.508 \\
\hline & Men & 65 & 2.324 & 0.618 & & \\
\hline \multirow{2}{*}{$\begin{array}{l}\text { Self-assertion in the expression } \\
\text { of positive affect }\end{array}$} & Women & 62 & 3.030 & 0.532 & 2.755 & $0.007^{* *}$ \\
\hline & Men & 65 & 2.775 & 0.508 & & \\
\hline \multirow{2}{*}{$\begin{array}{l}\text { Conversation and social } \\
\text { confidence }\end{array}$} & Women & 62 & 2.297 & 0.714 & 2.101 & $0.038^{*}$ \\
\hline & Men & 65 & 2.059 & 0.546 & & \\
\hline \multirow{2}{*}{$\begin{array}{l}\text { Self-exposure to unknown } \\
\text { people and new situations }\end{array}$} & Women & 62 & 2.012 & 0.844 & -1.302 & 0.195 \\
\hline & Men & 65 & 2.196 & 0.746 & & \\
\hline \multirow[t]{2}{*}{ Self-control of aggressiveness } & Women & 62 & 2.005 & 0.934 & 0.108 & 0.914 \\
\hline & Men & 65 & 1.9897 & 0.689 & & \\
\hline
\end{tabular}

${ }^{*} p$ value equal to significant level of $0.05 ;{ }^{* *} p$ value equal to significant level of 0.01

${ }^{a}$ Variables analyzed by $t$ test. Scores obtained by the Social Skills Inventory

women had higher social skills of keeping up conversation with strangers, participating in trivial conversation, asking questions to unknown people, negotiating the use of condom, and keeping up conversation in face-to-face contact.

\section{Discussion}

Assessment of social skills, from the Social Skills Inventory (Del Prette \& Del Prette, 2001) indicated deficits in the overall score of men, in self-exposure to unknown people and new situations in women, and conversation and social confidence and self-control of aggressiveness in assertive situations in men and women. These deficits indicate the need for interventions (Del Prette \& Del Prette, 2001), for instance, the social skills training (SST), to contribute to the drug user reinsertion and development of satisfactory social interactions.

Along with the assessment of deficits, SST planning in crack users should consider the differences, such as gender. Women had higher social skills in the overall score than men when comparing the social skills of men and women. This finding provides evidence that women were more skilled at social interaction than men in this population of crack users in a closed environment. In this perspective, it is understood that in the society, different repertoires are reinforced for men and women in behaviors considered skilled and unskilled (Caballo, 2003).

In addition to the differences in the overall score, the assessment of other social skills is crucial, considering the situational and contextual characteristics in which individuals are inserted (Lendering et al., 2011; Sá \& Del Prette, 2014). Thus, in conversation and social confidence skills, women had a significantly higher repertoire than men. There is evidence in a nonclinical population that points to higher conversation and social confidence skills in women when compared to men, according to a study with 167 Argentinian college students (García et al. 2014). Furthermore, it is emphasized that the normative reference of the instrument used in this study was also based on a nonclinical population. In the population evaluated by the instrument, differences were reported in specific items of social skills, but not in factors. Also, regarding alcohol users, a German study found higher losses in the approach to interpersonal conversation in women, and men had lower levels of social avoidance and difficulty approaching others (Muller et al., 2009). In this sense, the repertoire of social behavior should not be generalized to all drugs, noting that there are specific characteristics in the use of different substances, which may also explain the distinction between the studies with alcohol users and this study with crack users.

In the self-assertion in the expression of positive affect skill, women also had higher scores when compared to men. Since the first studies on social skills, there is evidence that women behave in a more skillful manner in the expression of positive feeling (Gambrill \& Richey, 1975; Hollandsworth \& Wall, 1977). Currently, it is identified that women are more expressive of positive emotions in virtual spaces (Thelwall et al. 2010; Park et al., 2011). In this perspective, it is important to emphasize that cultural roles have a direct relationship with learning social skills (Del Prette \& Del Prette, 2001). Therefore, from a cultural point of view, it can be understood that women often receive social encouragement to play roles of greater affectivity, by using different ways to express the positive feeling for better quality in intimate relationships (Caballo, 2003; Caballo et al., 2014; García et al., 2014). Thus, such issues seem to be also present in women crack users to seek and maintain the support 
Table 2 Comparison of specific social skills of men and women crack users, from the Social Skills Inventory

\begin{tabular}{|c|c|c|c|c|c|c|}
\hline Social Skills ${ }^{a}$ & Gender & N & Mean & SD & $T$ & $P$ \\
\hline \multirow[t]{2}{*}{ Keeping up conversation with strangers } & Men & 62 & 1.14 & 1.499 & 2.461 & $0.015^{*}$ \\
\hline & Women & 65 & 1.77 & 1.407 & & \\
\hline \multirow[t]{2}{*}{ Participating in trivial conversation ${ }^{\mathrm{b}}$} & Men & 62 & 2.29 & 1.308 & 3.646 & $0.0001^{* *}$ \\
\hline & Women & 65 & 1.47 & 1.238 & & \\
\hline \multirow{2}{*}{$\begin{array}{l}\text { Public presentation or lecture to an } \\
\text { unknown public }^{\mathrm{b}}\end{array}$} & Men & 62 & 1.46 & 1.308 & 3.264 & $0.001^{* *}$ \\
\hline & Women & 65 & 2.39 & 1.603 & & \\
\hline \multirow{2}{*}{$\begin{array}{l}\text { Addressing a partner for sexual } \\
\text { intercourse }\end{array}$} & Men & 62 & 2.43 & 1.457 & 2.468 & $0.015^{*}$ \\
\hline & Women & 65 & 1.77 & 1.541 & & \\
\hline \multirow[t]{2}{*}{ Dealing with unfair criticism } & Men & 62 & 3.05 & 1.430 & 2.038 & $0.044^{*}$ \\
\hline & Women & 65 & 2.53 & 1.411 & & \\
\hline \multirow[t]{2}{*}{ Returning defective product to the store } & Men & 62 & 3.55 & .952 & 3.163 & $0.002^{* *}$ \\
\hline & Women & 65 & 2.94 & 1.226 & & \\
\hline \multirow[t]{2}{*}{ Asking questions to unknown people } & Men & 62 & 2.65 & 1.515 & 3.710 & $0.0001^{* *}$ \\
\hline & Women & 65 & 1.68 & 1.423 & & \\
\hline \multirow[t]{2}{*}{ Ending a telephone conversation ${ }^{b}$} & Men & 62 & 1.11 & 1.501 & 2.021 & $0.045^{*}$ \\
\hline & Women & 65 & 1.65 & 1.494 & & \\
\hline \multirow[t]{2}{*}{ Dealing with fair criticism } & Men & 62 & 2.98 & 1.409 & 2.462 & $0.015^{*}$ \\
\hline & Women & 65 & 2.39 & 1.323 & & \\
\hline \multirow[t]{2}{*}{ Greeting strangers } & Men & 62 & 3.60 & 0.787 & 4.373 & $0.0001^{* *}$ \\
\hline & Women & 65 & 2.77 & 1.273 & & \\
\hline \multirow[t]{2}{*}{ Requesting help from friends } & Men & 62 & 0.62 & 1.100 & -7.503 & $0.0001^{* *}$ \\
\hline & Women & 65 & 2.24 & 1.327 & & \\
\hline \multirow[t]{2}{*}{ Negotiating the use of condom ${ }^{b}$} & Men & 62 & 1.91 & 1.693 & 3.180 & $0.002^{* *}$ \\
\hline & Women & 65 & 1.03 & 1.402 & & \\
\hline \multirow{2}{*}{$\begin{array}{l}\text { Keeping up a conversation in } \\
\text { face-to-face contact }\end{array}$} & Men & 62 & 3.00 & 1.468 & 4.835 & $0.0001^{* *}$ \\
\hline & Women & 65 & 1.79 & 1.345 & & \\
\hline \multirow[t]{2}{*}{ Asking a favor from colleagues ${ }^{b}$} & Men & 62 & 2.48 & 1.572 & 3.603 & $0.0001^{* *}$ \\
\hline & Women & 65 & 1.55 & 1.327 & & \\
\hline \multirow{2}{*}{$\begin{array}{l}\text { Dealing with parent's criticism and with } \\
\text { offensive mockery or games }\end{array}$} & Men & 62 & 2.97 & 1.392 & 2.143 & $0.034^{*}$ \\
\hline & Women & 65 & 2.42 & 1.499 & & \\
\hline
\end{tabular}

${ }^{*} p$ value equal to the significant level of $0.05 .{ }^{* *} p$ value equal to significant level of 0.005

Variables analyzed by $t$ test:

${ }^{a}$ Content assessed in the Social Skills Inventory items.

b Inverted items in the Inventory, the higher the score is, the lower the social skill is

network, given that the lack of social support is a risk factor for relapse in women substance users (Fahrudin \& Nurdin, 2010).

Considering the differences in social skills of men and women, it is comprehended that women crack users have a higher need for a support network in their recovery process in the treatment for substance use. Therefore, the individual exercises social skills to maximize gains and reduce losses (Del Prette \& Del Prette, 2014). Moreover, social conversation can be exercised by women to seek social support, representing a gain for women drug users in treatment (Fahrudin \& Nurdin, 2010).

\section{Situational social skills}

Social skills can be categorized as situational and contextual and are behaviors of specific interactions (Del Prette \& Del Prette, 2001). Significant differences between men and women were also found when situational skills were compared. The skills of keeping up and participating in a conversation, and asking questions, relate to the conversation and social confidence skills, which are higher among women, corroborating with the results regarding behavior classes. In this sense, it is understood that empathy, which was assessed as higher in the female population, may be a major influence on better 
interpersonal interaction regarding aspects of conversation (Mestre et al. 2009).

Treatment context should also be considered when assessing specific social skills since it can influence social behavior institutional rules. Men participants of this study were in treatment in the therapeutic communities, where they have as a principle to be an organized society, with the well-structure system, rules, and standards to be met, prioritizing healthy relationships and effective participation in mutual-help groups (Perrone, 2014). In this perspective, these treatment institutions require from patients skills like greeting strangers, public presentations or lecture to an unknown public, and even asking a favor from colleagues. These skills were higher among men when compared to women, suggesting an influence of their treatment context and specific characteristics of this male population.

Following the understanding of specific situational skills, women had higher skills in negotiating the use of condom, even if she has to disagree with her partner. This skill is very relevant, considering studies that indicate prostitution as a means of obtaining crack (Correa et al. 2008; Malta, et al., 2008; Nappo et al. 2011). In turn, men are more skilled in returning defective merchandising to the store, addressing the other for sexual intercourse and expressing annoyance to a relative. Such behaviors are included in the coping and self-assertion with risk skills, which integrate behaviors of defense of your rights, even with the risk of rejection (Del Prette \& Del Prette, 2001). Furthermore, the skill of ending a telephone conversation, which was higher in men in this study, was positively correlated with crack use in a study performed with drug users who were mostly men (Sá \& Del Prette, 2014).

It is noteworthy that men in this study showed higher skills in dealing with fair and unfair criticism, as well as in dealing with parent's criticism and with offensive mockery or games. On the other hand, women had greater difficulties in expressing their needs to others and higher social anxiety regarding criticism and rejection, corroborating with data found in the literature (Caballo et al., 2014; Muller et al., 2009). According to a systematic review, which sought to identify studies on impulsivity in alcoholics, women tend to have higher inhibition in seeking satisfaction for the need of other to maintain a pro-social environment (Pasa \& Almeida, 2010). A study with adolescents demonstrated that low social competence is an influencing factor for the onset of smoking among girls but not among boys, emphasizing that girls tend to accept more easily the pressure of peers for fear of not fitting in with the group (Westling et al. 2012). In this perspective, Ribeiro and Laranjeira (2012) highlight that the very feeling of love and companionship, combined with the fear of not being accepted, influences the difficulty of denying crack when someone close offers it. Such aspects reinforce the relevance of intervening in learning and/or improvement of defense of rights, rejecting abusive requests and dealing with unfair criticism skills in the female population, since such losses may pose the greatest risk factors for addictive behaviors among women.

\section{Implications for the social skills training}

Based on these findings, it is possible to propose some considerations regarding the SST with men and women crack users. It is emphasized that the assessment of social skills should support the planning of the intervention. In addition to self-report instruments, behavior observations may complement the assessment. According to the results of this study, the emphasis of SSI in women should be in deficit factors of social skills. Moreover, it is necessary to identify the skills in which there is greater ease, for example, the expression of positive feelings, to be the first skill to be worked on at SST so that the intervention occurs in ascending order of difficulty (Del Prette \& Del Prette, 2014). Specific skills like dealing with parent's criticism and with offensive mockery or games should also be worked on, because they relate to the difficulties of such women in the expression of negative feelings and unpleasantness and can be characterized as a risk factor for relapse in drug use (Limberger et al. 2016; Limberger \& Andretta, in press). In this perspective, it is also relevant to develop skills to deal with criticism, since this is a risk factor for relapse. Considering the social stigma and low self-esteem in women crack users, it is important that the treatments include the learning of defense of rights skills for greater autonomy in the social reinsertion process (Kuri et al. 2015).

In turn, the SST with men crack users should include learning about aspects related to conversation and social confidence, highlighting the importance of these behaviors for the resumption of social and professional life after treatment. The development of expressing positive feelings also becomes relevant to social reintegration, providing an affective approach to family and friends, as isolation is typical in this population during the consumption of crack (Kessler et al., 2012; Ribeiro \& Laranjeira, 2012). A SST focused on both mentioned skills will involve aspects related to the development of empathy, regulation of impulsive behavioral responses, and improvement of assertiveness (Del Prette \& Del Prette, 2014). These aspects will also help with socially skilled behaviors in relation to self-control of aggressiveness, stressing that such skills have also shown to be impaired in men crack users when compared with men non-drug users (Schneider, 2015).

\section{Conclusions}

The presence of deficits in social skills of men and women expresses the need for social skills training with 
this population. Therefore, this intervention should be conducted considering their specificities and the significant differences found. In this study, we identified a greater need for women crack user to deal with negative feelings and expressing unpleasantness, while a higher need of men in the expression of positive feelings and social confidence was reported. Thereby, it was possible to expose implications for the Social Skills Training in crack users, so that this intervention contributes to the social reinsertion during and after treatment. It is suggested that future studies should assess the effectiveness of the Social Skills Training, identifying factors that contribute to the development of socially skilled behaviors.

\section{Authors' contributions}

IA contributed to the conception of the study, interpretation, writing, revising, and supervision; $J \mathrm{~L}$ was involved in the conception of the study, data collection, analysis, and writing; JAS was involved in the conception of the study, data collection, analysis, and writing. All authors read and approved the final manuscript.

\section{Competing interests}

The authors declare that they have no competing interests.

Received: 1 September 2016 Accepted: 9 November 2016 Published online: 24 November 2016

\section{References}

Alexandre, N. L., Del Río, M. P., \& Pol, A. P. (2004). Estrategias de afrontamiento: factores de protecciónenel consumo de alcohol, tabaco y cannabis. Adicciones, 4(16), 1-6.

Aliane, P. P., Lorenço, L. M., \& Ronzani, T. M. (2006). Estudo comparativo das habilidades sociais de dependentes e não dependentes de álcool. Psicologia em Estudo, 11(1), 160-171. doi:10.1590/S1413-73722006000100010.

American Psychiatric Association [APA]. (2002). Manual diagnóstico e estatístico dos transtornos mentais. DSM IV-TR. 4a ed. Porto Alegre: Artes Médicas.

American Psychiatric Association [APA]. (2014). Manual Diagnóstico e Estatístico de Transtornos Mentais. DSM-5. Porto Alegre: Artmed.

Amorim, P. (2000). Mini International Neuropsychiatric Interview (MINI): validação de entrevista breve para diagnóstico de transtornos mentais. Revista Brasileira de Psiquiatria, 22(3), 106-115. doi:10.1590/S1516-44462000000300003.

Associação Brasileira de Empresas de Pesquisa [ABEP]. (2015). Critérios de Classificação Econômica Brasil. http://goo.gl/vQWl17. Acessed 01 Aug 2016.

Bartolomeu, D., Nunes, C. H. S. S., \& Machado, A. A. (2008). Traços de personalidade e habilidades sociais em universitários. Psico-USF, 13(1), 41-50.

Bolsoni-Silva, A. T., Rocha, J. F., Cassetari, B. M., Daroz, R., \& Loureiro, S. R. (2011). Habilidades sociais, saúde mental e universitários: possíveis relações. Comportamento em foco, 1(1), 77-86.

Caballo, V. E. (2003). Manual de avaliação e treinamento das habilidades sociais. São Paulo: Livraria Santos.

Caballo, V. E., Salazar, I. S., Irurtia, M. J., Arias, B., \& Hoffmann, S. G. (2014). Differences in social anxiety between men and women across 18 countries. Pers Individ Dif., 64, 35-40. doi:10.1016/j.paid.2014.02.013.

Correa, N. A. B., Matumoto, F. H., \& Lonardi, M. V. C. (2008). Doenças sexualmente transmissíveis em mulheres profissionais do sexo, Umuarama, Estado do Paraná. RBAC, 40(3), 209-213.

Cunha, J. A. (1993). Psicodiagnóstico-R (4th ed.). Porto Alegre: Artes Médicas.

Cunha, S. M., Carvalho, J. C. N., Kolling, N. M., Silva, C. R., \& Kristensen, C. H. (2007), Habilidades sociais em alcoolistas: um estudo exploratório. Revista Brasileira de Terapias Cognitivas, 3(1), 28-41.

Cunha, S. M., Peuker, A. C., \& Bizarro, L. (2012). Consumo de Álcool de Risco e Repertório de Habilidades Sociais entre Universitários. Psico, 43(3), 289-297.

Del Prette, Z. A. P., \& Del Prette, A. (2001). Inventário de Habilidades Sociais: Manual de aplicação, apuração e interpretação. São Paulo: Casa do Psicólogo.

Del Prette, A., \& Del Prette, Z. A. P. (2014). Psicologia das relações interpessoais: vivências para o trabalho em grupo. Rio de Janeiro: Vozes.
Diehl, A., Cordeiro, D. C., \& Laranjeira, R. (2011). Dependência Química: prevenção, tratamento e políticas públicas. Porto Alegre: Artmed.

Fahrudin, A., \& Nurdin, D. (2010). Coping strategies and relapse of substance abusers: a case study of the therapeutic community program in Indonesia. Asian Social Workand Policy Review, 4(2), 98-117. doi:10.1111/j.1753-1411. 2010.00040.x

Feldens, A. C. M., Silva, J. G. D., \& Oliveira, M. D. S. (2011). Avaliação das funções executivas em alcoolistas. Cadernos de Saúde Coletiva, 19, 164-171.

Fischer, B., Blanken, P., Da Silveira, D., Gallassi, A., Goldner, E. M., Rehm, J., \& Wood, E. (2015). Effectiveness of secondary prevention and treatment interventions for crack-cocaine abuse: a comprehensive narrative overview of Englishlanguage studies. International Journal of Drug Policy, 26(4), 352-363. doi:10.1016/j.drugpo.2015.01.002.

Gambrill, E. D., \& Richey, C. A. (1975). An assertion inventory for use in assessment and research. Behavior Therapy, 6(4), 550-561. doi:10.1016/S0005-7894(75)80013-X.

García, M., Cabanillas, G., Morán, V., \& Olaz, F. (2014). Diferencias de género en habilidades sociales en estudiantes universitarios de Argentina. Anuario Electrónico de Estudios en Comunicación Social "Disertaciones", 7(2), 114-135. doi:10.12804\%2Fdisertaciones.v7i2.4622.

Hollandsworth, J. G., \& Wall, K. (1977). Sex differences in assertive behavior: an empirical investigation. Journal of Counseling Psychology, 24(3), 108-111. doi: 10.1037/0022-0167.24.3.217

Kessler, F. H. P., Terra, M. B., Falle, S., Stolf, A. R., Peuker, A. C., Benzano, D., \& Pechansky, F. (2012). Crack user show high rates of antisocial personality disorder, engagement in illegal activities and other psychosocial problems. The American Journal on Addiction, 21, 370-380. doi:10.1111/j.1521-0391.2012. 00245.x.

Kuri, S. E. R., Alcaráz, A. J. C., \& Cáceres, M. D. C. F. (2015). Estudio comparativo del proceso de inserción social en hombres y mujeres usuarios de drogas en rehabilitación. Health and Addictions/Salud y Drogas, 15(1), 49-54.

Lendering, G. M. F., Huijbregts, S. C., Huizink, A. C., Ormel, H., Verhulst, F. C., Vollebergh, W. A., \& Swaab, H. (2011). Social skills as precursors of cannabis use in young adolescents: a TRAlLS study. Journal of Clinical Child \& Adolescent Psychology, 40(5), 706-714. doi:10.1080/15374416.2011.597085.

Limberger, J., \& Andretta, I. (2017). Desenvolvimento das Habilidades Sociais na Vida de Mulheres Usuárias de Crack: Estudo de Casos Múltiplos. Temas em Psicologia, 25(4).

Limberger, J., Nascimento, R. S., Schneider, J. A., \& Andretta, I. (2016). Women users of crack: systematic review of Brazilian literature. Jornal Brasileiro de Psiquiatria, 65(1), 82-88. doi:10.1590/0047-2085000000107.

Malta, M., Monteiro, S., Lima, R. M. J., Bauken, S., Marco, A., Zuim, G. C., \& Strathdee, S. A. (2008). HIV/AIDS risk among female sex workers who use crack in Southern Brazil. Revista de Saúde Pública, 42(5), 831-837. doi:10.1590/ S0034-89102008000500007.

Mestre, M. V., Samper, P., Frías, M. D., \& Tur, A. M. (2009). Are women more empathetic than men? A longitudinal study in adolescence. The Spanish Journal of Psychology, 12(1), 76-83. doi:10.1017/S1138741600001499.

Muller, S. E., Degen, B., Perirjean, S., Wiesbeck, G. A., \& Walter, M. (2009). Gender differences in interpersonal problems of alcohol-dependent patients and healthy controls. International Journal of Environmental Research and Public Health, 6(12), 3010-3022. doi:10.3390/ijerph6123010.

Nappo, S. A., Sanchez, Z., \& Oliveira, L. G. (2011). Crack, AIDS, and women in São Paulo, Brazil. Substance Use \& Misuse, 46, 476-485. doi:10.3109/10826084.2010.503480.

Nascimento, E. (2004). Adaptação e padronização brasileira da Escala de Inteligência Wechsler para Adultos. Porto Alegre: Casa do Psicólogo.

Papalia, D. E., \& Feldman, S. W. (2013). Desenvolvimento humano (12th ed.). Porto Alegre: Amgh.

Park, K. M., Ku, J., Choi, S. H., Jang, H. J., Park, J. Y., Kim, S. I., \& Kim, J. J. (2011). A virtual reality application in role-plays of social skills training for schizophrenia: a randomized, controlled trial. Psychiatry Research, 189(2), 166-172. doi:10.1016/j. psychres.2011.04.003.

Pasa, M. S. G. G., \& Almeida, R. M. M. (2010). Dependência de álcool, cocaína e crack e transtornos psiquiátricos. Psicologia: teoria e pesquisa, 26(3), 533-541. doi:10.1590/S0102-37722010000300016.

Perrone, P. A. K. (2014). A comunidade terapêutica para recuperação da dependência do álcool e outras drogas no Brasil: mão ou contramão da reforma psiquiátrica? Ciênc. saúde coletiva, 19(2), 569-580. doi:10.1590/1413-81232014192.00382013.

Ribeiro, M., \& Laranjeira, R. (2012). O tratamento do usuário de crack (2nd ed.). Porto Alegre: Artmed.

Sá, L. G. S., \& Del Prette, Z. A. P. (2011). Correlação entre habilidades sociais e nível de envolvimento com álcool, maconha e cocaína/crack em 
dependentes químicos. Anais do IV Seminário Internacional de Habilidades Sociais. http://goo.gl/LIVsZV. Acessed 01 Aug 2016.

Sá, L. G. C., \& Del Prette, Z. A. P. (2014). Habilidades sociais como preditoras do envolvimento com álcool e outras drogas: um estudo exploratório. Interação em Psicologia, 18(2), 167-178. doi:10.5380/psi.v18i2.30660.

Sampieri, R. H., Collado, C. F., \& Lucio, M. P. B. (2013). Metodologia de Pesquisa. Porto Alegre: Penso.

Schneider, J. A. (2015). Avaliação de Habilidades Sociais nos Usuários de Crack em Tratamento no Contexto das Comunidades Terapêutica (Dissertação, Universidade do Vale do Rio dos Sinos). http://goo.gl/7GWnb8. Acessed 01 Aug 2016.

Schneider, J. A., Limberger, J., \& Andretta, I. (2016). Habilidades Sociais e Drogas: Revisão Sistemática da Produção Científica Nacional e Internacional. Avances em Psicología Latinoamericana, 34(2), 339-350. doi:10.12804/apl34.2.2016.08.

Sheehan, D. V., Lecrubier, Y., Sheehan, K. H., Amorim, P., Janavs, J., Weiller, E., \& Dunbar, G. C. (1998). The Mini-International Neuropsychiatric Interview (M.IN. I.): the development and validation of a structured diagnostic psychiatric interview for DSM-IV and ICD-10. Journal Clinic Psychiatry, 59(supl. 20), 22-33.

Sintra, C. I. F., Lopes, P., \& Formiga, N. (2011). Condutas antissociais e delitivas e habilidades sociais em contexto forense. Psicologia e Argumento, 29, 383-399.

Spronk, D. B., van Wel, J. H., Ramaekers, J. G., \& Verkes, R. J. (2013). Characterizing the cognitive effects of cocaine: a comprehensive review. Neuroscience \& Biobehavioral Reviews, 37(8), 1838-1859. doi:10.1016/j.neubiorev.2013.07.003.

Thelwall, M., Wilkinson, D., \& Uppal, S. (2010). Data mining emotion in social network communication: gender differences in MySpace. Journal of the American Society for Information Science and Technology, 61(1), 190-199. doi:10.1002/asi.21180.

Wagner, M. F., \& Oliveira, M. S. (2015). Habilidades sociais no abuso e na dependência de maconha. In Z. A. P. Del Prette, A. B. Soares, C. S. PereiraGuizo, M. F. Wagner, \& V. B. R. Leme (Eds.), Habilidades sociais: diálogos e intercâmbios sobre pesquisa e prática. Novo Hamburgo: Sinopys Editora.

Wechsler, D. (1997). Weschsler Adult Intelligence Scale-III. San Antonio: The Psychological Corporation.

Westling, E., Andrews, J. A., \& Peterson, M. (2012). Gender differences in puberta timing, social competence, and cigarette use: a test of the early maturation hypothesis. Journal of Adolescent Health, 51(2), 150-155. doi:10.1016/j. jadohealth.2011.11.021.

\section{Submit your manuscript to a SpringerOpen ${ }^{\circ}$ journal and benefit from:}

- Convenient online submission

- Rigorous peer review

- Immediate publication on acceptance

- Open access: articles freely available online

High visibility within the field

- Retaining the copyright to your article 